\title{
Erratum to: Multi-cell nuclei segmentation in cervical cancer images by integrated feature vectors
}

\author{
Arti Taneja $^{1} \cdot$ Priya Ranjan $^{2} \cdot$ Amit Ujlayan $^{3}$
}

Published online: 31 August 2017

(C) Springer Science+Business Media, LLC 2017

Erratum to: Multimed Tools Appl

DOI: $10.1007 / \mathbf{s} 11042-017-4864-x$

In the original publication, the photographs of Drs. Priya Ranjan and Amit Ujlayan were interchanged. The original article has been corrected.

The online version of the original article can be found at http://dx.doi.org/10.1007/s11042-017-4864-x

\section{Arti Taneja}

arti.taneja@gmail.com

1 Amity Institute of Information Technology, Noida, Uttar Pradesh 201303, India

2 Amity University, Noida, Uttar Pradesh, India

3 Gautam Budha University, Greater Noida, India 